\title{
PENGARUH PEMBELAJARAN PROBLEM SOLVING TERHADAP KEMAMPUAN BERPIKIR KREATIF MATEMATIS SISWA
}

\author{
Ahmad Fadillah \\ Universitas Muhammadiyah Tangerang \\ fadiel_algebra@yahoo.co.id
}

\begin{abstract}
Abstrak
Tujuan dari penelitian ini adalah untuk mengetahui perbedaan kemampuan berpikir kreatif matematis siswa. Kelompok eksperimen menggunakan pembelajaran problem solving dan kelompok kontrol menggunakan pembelajaran konvensional. Metode yang digunakan dalam penelitian ini adalah metode quasi eksperimen jenis nonequivalent control group design. Dengan sampel penelitian adalah siswa kelas 8.1 yang berjumlah 31 siswa sebagai kelas eksperimen dan siswa kelas 8.2 yang berjumlah 31 siswa sebagai kelas kontrol. Berdasarkan hasil pengujian hipotesis terhadap nilai gain diperoleh $t_{\text {hitung }}=3,33$, dan $t_{\text {tabel }}=2,000$ pada taraf signifikansi $\alpha=5 \%$ sehingga dapat disimpulkan bahwa terdapat perbedaan yang signifikan kemampuan berpikir kreatif matematis siswa antara kelas eksperimen dan kelas kontrol.
\end{abstract}

Kata Kunci: Berpikir Kreatif, Problem Solving

\section{PENDAHULUAN}

Matematika sebagai salah satu disiplin ilmu mempunyai peranan penting dalam mengembangkan kemampuan peserta didik termasuk kemampuan berpikirnya. Hal ini sesuai dengan Standar Nasional Pendidikan bahwa tujuan pembelajaran matematika diharapkan dapat memberikan penataan nalar, berpikir kritis, pembentukan sikap siswa serta kemampuan penerapannya dalam kehidupan sehari-hari maupun dalam mempelajari berbagai ilmu pengetahuan (Depdiknas, 2004). Menurut Ruseffendi dalam (Miliyawati, 2012) menyatakan bahwa matematika terbentuk sebagai hasil pemikiran manusia yang berhubungan dengan ide, proses, dan penalaran. Dengan kata lain, matematika sebagai ilmu yang mengembangkan sikap berpikir kritis, dinamis, dan terbuka tidak dapat dipisahkan dengan penalaran. Hal ini sejalan dengan tujuan Kurikulum 2013, yaitu 
mempersiapkan generasi bangsa agar memiliki kemampuan hidup sebagai pribadi dan warga negara yang produktif, kreatif, inovatif, dan afektif.

Pembelajaran matematika di sekolah diharapkan mampu mewujudkan tujuan pembelajaran matematika yang dirumuskan oleh Depdiknas (2006) yaitu (1) melatih cara berpikir dan bernalar dalam menarik kesimpulan, (2) mengembangkan aktivitas kreatif yang melibatkan imajinasi, intuisi, dan 3 penemuan dengan mengembangkan pemikiran divergen, orisinil, rasa ingin tahu, membuat prediksi dan dugaan, serta mencoba-coba, (3) mengembangkan kemampuan pemecahan masalah, dan (4) mengembangkan kemampuan menyampaikan informasi dan mengkomunikasikan gagasan. Penekanan pembelajaran matematika di sekolah tidak hanya pada melatih keterampilan dan menghafal fakta, tetapi juga pada pemahaman konsep. Tidak hanya hasil tetapi juga bagaimana dan mengapa soal tersebut diselesaikan dengan cara tertentu dengan tetap menyesuaikan pada kemampuan berpikir siswa. Kenyataannya di lapangan, pembelajaran matematika masih bersifat drill dan tidak menunjukkan keterkaitan antarkonsep sehingga belum mampu mewujudkan tujuan diberikannya pembelajaran matematika di sekolah.

Sri Wardhani (2008) menyatakan salah satu Standar Kompetensi Lulusan Mata Pelajaran Matematika di tingkat Sekolah Menengah Pertama (SMP) dan Madrasah Tsanawiyah (MTs) adalah siswa harus memiliki kemampuan untuk berpikir logis, analitis, sistematis, kritis, dan kreatif, serta mempunyai kemampuan bekerja sama. Berdasarkan hal tersebut, pendidikan di Indonesia harus diselenggarakan dengan cara memberikan kesempatan siswa untuk berpartisipasi aktif serta mampu meningkatkan kemampuan berpikir kreatif siswa.

Kenyataan di lapangan menunjukan bahwa tidak mudah bagi guru terutama guru matematika untuk dapat melaksanakan proses pembelajaran yang sesuai dengan Standar Nasional Pendidikan serta memenuhi Standar Kompetensi Lulusan Mata Pelajaran Matematika. Kelemahan ini membuat hasil pembelajaran matematika belum mampu mengikuti persaingan tingkat Internasional.Berdasarkan laporan National Council of Teachers of Mathematics (NCTM) 2011, siswa kelas VIII Indonesia menempati posisi ke 38 dari 42 negara yang berpartisipasi dalam tes matematika. Hasil ini tidak jauh berbeda dengan hasil survey dari lembaga lain seperti Programme for International Student Asessment (PISA). Berdasarkan hasil survey PISA tahun 2012, kemampuan matematika siswa Indonesia menempati urutan ke-64 dari 65 Negara peserta. Dari hasil survey kedua lembaga tersebut, memberikan gambaran adanya masalah dalam sistem pendidikan di Indonesia khususnya pendidikan dan pembelajaran matematika. 
Rendahnya hasil pembelajaran matematika di tingkat Internasional, tentunya berawal dari rendahnya hasil pembelajaran di tingkat nasional. Penggunaan soal-soal matematika dengan taraf kognitif yang rendah, membuat siswa di Indonesia belum terbiasa menghadapi soal-soal di tingkat Internasional yang memiliki taraf kognitif yang tinggi. Hal ini ditunjukan dalam kajian tentang aspek kognitif soal Ujian Nasional Sekolah Menengah Pertama (SMP) tahun 2009/2010 dan 2010/2011 yang dilakukan oleh Erika Sandrayani, Budi Murtiyasa, dan Masduki tahun 2012, dengan kesimpulan bahwa taraf kognitif soal-soal Ujian Nasional Matematika SMP masih sangat rendah, karena lebih dari 50\% soal memiliki aspek pengetahuan. Sementara untuk soal-soal penerapan hanya mencapai $22.50-27.50 \%$ dan penalaran hanya mencapai $10-17.50 \%$ dari jumlah soal yang diujikan.

Berdasarkan kajian tersebut, dapat disimpulkan bahwa siswa di Indonesia tidak diberikan tantangan untuk menyelesaikan permasalah-permasalahan yang kompleks yang menuntut kemampuan berpikir kreatif, kritis, dan analitis. Padahal kemampuan berpikir kreatif, kritis, dan analitis sangat diperlukan untuk menghadapi permasalahan di masa yang akan datang serta sebagai modal untuk mampu bersaing di tingkat Internasional.

Menurut Utami Munandar (2012: 167), “berpikir kreatif adalah memberikan macammacam kemungkinan jawaban berdasarkan informasi yang diberikan dengan penekanan pada keragaman jumlah dan kesesuaian”. Dengan kata lain, kemampuan berpikir kreatif adalah proses yang dilakukan oleh seseorang untuk mengembangkan suatu persoalan menjadi alternatif jawaban. Kemampuan berpikir kreatif yang diterapkan dalam pembelajaran matematika, dikenal dengan istilah kemampuan berpikir kreatif matematis. Kemampuan berpikir kreatif matematis adalah proses yang dilakukan oleh seseorang untuk mengembangkan suatu persoalan menjadi alternatif jawaban dalam memecahkan persoalanpersoalan yang berhubungan dengan logika, pola dan urutan yang sistematis.

Guilford mengembangkan indikator kemampuan berpikir kreatif yaitu pertama berpikir lancar (fluency), yaitu kemampuan untuk menghasilkan banyak gagasan yang relevan dengan arus pemikiran yang lancar. Kedua berpikir luwes (flexibility), yaitu kemampuan untuk menghasilkan pemikiran yang berbeda-beda dan mampu mengubah cara atau pendekatan. Dan ketiga berpikir terperinci (elaboration), yaitu kemampuan membangun ide yang beragam, yaitu kemampuan untuk mencoba berbagai pendekatan dalam memecahkan masalah. (Akhmad Jazuli, 2009).

Sistem pembelajaran yang belum terealisasikan dengan baik membuat proses pembelajaran masih berpusat pada guru. Sehingga kemampuan berpikir kreatif siswa tidak dapat berkembang secara maksimal. Hal tersebut, sesuai dengan hasil pengamatan yang 
dilakukan di Madrasah Tsanawiyah. Hasil pengamatan menemukan bahwa kemampuan berpikir kreatif siswa masih sangat rendah dalam proses pembelajaran matematika. Hal ini ditunjukkan dalam soal-soal ulangan yang sebagian besar menggunakan aspek pengetahuan dan pemahaman. Hal ini tentu saja menjadi salah satu penyebab kurang berkembangnya kemampuan berpikir kreatif pada siswa dalam pembelajaran matematika.

Utami Munandar (2012: 227) menyatakan beberapa faktor yang menjadi kendala dalam mengembangkan kemampuan berpikir kreatif siswa di sekolah. Faktor-faktor tersebut antara lain sikap guru yang terlalu banyak mengontrol, mekanisme belajar dengan cara menghafal, kondisi psikologis siswa, serta proses pembelajaran yang kurang menantang dan menstimulus kompetensi siswa. Mekanisme belajar dengan cara menghafal serta proses pembelajaran yang kurang menantang dan menstimulus kompetensi siswa merupakan salah satu kendala yang perlu diperbaiki. Penggunaan strategi pembelajaran yang tepat tentunya menjadi satu solusi yang dapat diterapkan dalam proses pembelajaran.

Momon Sudarma (2013: 48) mengemukakan bahwa sudah banyak diperkenalkan model pembelajaran yang merangsang siswa untuk dapat berpikir kritis dan kreatif. Salah satu diantaranya, yaitu model pembelajaran berbasis pemecahan masalah (problem solving based learning).

Problem Solving merupakan suatu strategi pembelajaran dengan menggunakan penyelesaian masalah yang bersifat terbuka sehingga mampu mendorong siswa berpikir kreatif. Dari serangkaian penyelesaian masalah yang bersifat terbuka itu diharapkan siswa mampu menemukan jawaban yang bervariatif atas dasar kreativitas dan kemampuannya sendiri.

Ridwan Abdullah Sani (2013: 243) berpendapat bahwa strategi problem solving sangat potensial untuk melatih siswa berpikir kreatif dalam menghadapi berbagai masalah baik itu masalah pribadi maupun masalah kelompok untuk dipecahkan sendiri atau secara bersamasama. Untuk itu, strategi problem solving dipilih karena diharapkan mampu meningkatkan kemampuan berpikir kreatif siswa dalam bidang matematika.

Wankat dan Oreovocz telah mengembangkan langkah-langkah strategi pembelajaran problem solving yang dimulai dengan tahap saya bisa ( $\mathrm{c}$ can), yaitu tahap dimana siswa menumbuhkembangkan motivasi belajar dan keyakinan diri dalam menyelesaikan permasalahan. Selanjutnya tahap mendefinisikan (define), berupa tahap menganalisis dan membuat daftar hal yang diketahui dan tidak diketahui dalam suatu permasalahan. Yang ketiga, tahap mengeksplorasi (explore), berupa tahap mengajukan pertanyaan pada guru, untuk melakukan pengkajian lebih dalam terhadap permasalahan yang dibahas. Keempat, 
tahap merencanakan (plan), yaitu tahap berlatih mengembangkan cara berpikir logis dan kreatif untuk menghadapi masalah yang dihadapi. Kelima, tahap mengerjakan (do it), yaitu tahap dimana siswa mencari berbagai alternatif pemecahan masalah. Keenam, tahap mengoreksi kembali (check), yaitu tahap mengecek tingkat kebenaran jawaban yang ada. Dan terakhir tahap generalisasi (generalize), yaitu tahap memilih atau menentukan pertanyaan dan jawaban yang tepat (Made Wena, 201: 57).

Tujuan dari penelitian ini adalah untuk mengetahui ada tidaknya perbedaan kemampuan berpikir kreatif matematis siswa pada materi operasi hitung bentuk aljabar antara siswa yang diberi strategi pembelajaran problem solving dengan siswa yang diberi strategi pembelajaran konvensional. Serta untuk mengetahui ada tidaknya perbedaan peningkatan kemampuan berpikir kreatif matematis siswa pada materi operasi hitung bentuk aljabar antara siswa yang diberi strategi pembelajaran problem solving dengan siswa yang diberi strategi pembelajaran konvensional.

\section{METODE PENELITIAN}

Penelitian ini dilaksanakan di SMPN 10 Tangerang pada semester ganjil tahun pelajaran 2015-2016. Metode yang digunakan dalam penelitian ini adalah Quasi Experiment dengan jenis Nonequivalent Control Group Design.Populasi target dalam penelitian ini adalah seluruh siswa di SMPN 10 Tangerang. Sedangkan populasi terjangkau dalam penelitian ini adalah seluruh siswa kelas VIII. Teknik pengambilan sampel penelitian dengan simplerandom sampling. Adapun kelas yang terpilih sebagai kelas kontrol adalah kelas 8.2 yang berjumlah 31 siswa dengan menggunakan strategi pembelajaran konvensional dengan metode ceramah disertai diskusi. Sedangkan kelas eksperimen adalah kelas 8.1 yang berjumlah 31 siswa dengan menggunakan strategi pembelajaran problem solving yang dikembangkan oleh Wankat dan Oreovocz.

Teknik pengumpulan data dalam penelitian ini adalah dengan menggunakan tes. Tes yang digunakan berupa soal uraian terbuka. Tes dengan soal uraian terbuka digunakan karena jawaban yang dihasilkan dalam bentuk menguraikan, menjelaskan, mengekspresikan gagasan, membandingkan, memberikan alasan dengan menggunakan kata-kata dan bahasa sendiri sehingga diharapkan dapat memunculkan kemampuan berpikir kreatif siswa.

Tes tersebut terlebih dahulu diujicobakan untuk mengetahui validitas dan reliabilitas instrument penelitian. Analisis data dalam penelitian ini menggunakan uji t dengan rumus the pooled variance model t-test. Uji prasyarat meliputi uji normalitas yang menggunakan rumus chi-kuadrat untuk data pretes dan postes, sedangkan untuk data gain dilakukan uji normalitas 
liliefors dengan bantuan aplikasi SPSS 20. Serta uji homogenitas yang menggunakan uji Fisher.

\section{HASIL DAN PEMBAHASAN}

Berdasarkan hasil rekapitulasi data hasil pretes dan postes antara kelas eksperimen (problem solving) dan kelas kontrol (konvensinal) diperoleh hasil bahwa terdapat perbedaan kemampuan berpikir kreatif matematis siswa yang diberi pembelajaran problem solving dengansiswa yang diberi pembelajaran konvensional. Dengan nilai rata-rata gain siswa yang diberi pembelajaran problem solving lebih baik dari siswa yang diberi pembelajaran konvensional. Hal ini dapat dilihat dari tabel-tabel berikut:

Tabel 1: Rekapitulasi Data Hasil Pretes dan Posttes

\begin{tabular}{|l|c|c|c|c|}
\hline \multirow{2}{*}{\multicolumn{1}{|c|}{ Hasil data }} & \multicolumn{2}{c|}{ Pretest } & \multicolumn{2}{c|}{ Post test } \\
\cline { 2 - 5 } & Eksperimen & Kontrol & Eksperimen & Kontrol \\
\hline Banyak Data Sampel (n) & 31 & 31 & 31 & 31 \\
\hline Nilai Minimum $\left(\mathrm{D}_{\min }\right)$ & 10 & 10 & 63 & 47 \\
\hline Nilai Maksimum $\left(\mathrm{D}_{\max }\right)$ & 47 & 43 & 100 & 93 \\
\hline Range / Rentang Data $(\mathrm{r})$ & 37 & 33 & 37 & 46 \\
\hline Banyak Kelas $(\mathrm{k})$ & 6 & 6 & 6 & 6 \\
\hline Interval Kelas $(\mathrm{i})$ & 7 & 6 & 7 & 8 \\
\hline Rata-Rata Kelas $(\overline{\mathrm{x}})$ & 23.61 & 25.08 & 81.58 & 73.98 \\
\hline Median $(\mathrm{Me})$ & 21.75 & 24.96 & 81.46 & 74.5 \\
\hline Modus $(\mathrm{Mo})$ & 20.21 & 25 & 81.35 & 74.5 \\
\hline Varians $\left(\mathrm{S}^{2}\right)$ & 71.44 & 41.65 & 83.99 & 119.19 \\
\hline Simpangan Baku $(\mathrm{S})$ & 8.45 & 6.45 & 9.16 & 10.92 \\
\hline
\end{tabular}

Tabel 2: Perhitungan Uji Normalitas Data Pretes dan Posttes

\begin{tabular}{|c|c|c|c|c|}
\hline Data & Kelas & $\boldsymbol{\chi}^{\mathbf{2}}{ }_{\text {hitung }}$ & $\boldsymbol{\chi}^{\mathbf{2}}$ table & Kesimpulan \\
\hline \multirow{2}{*}{ Pretes } & Eksperimen & 6.7964 & 11,07 & Data menyebar normal \\
\cline { 2 - 5 } & Kontrol & 2.5216 & 11,07 & Data menyebar normal \\
\hline \multirow{2}{*}{ Postes } & Eksperimen & 5.5011 & 11.07 & Data menyebar normal \\
\cline { 2 - 5 } & Kontrol & 2.0301 & 11.07 & Data menyebar normal \\
\hline
\end{tabular}

Tabel 3: Perhitungan uji homogenitas data pretes dan posttes

\begin{tabular}{|c|c|c|c|c|c|}
\hline Data & Kelas & $\mathbf{S}^{\mathbf{2}}$ & $\mathbf{F}_{\text {hitung }}$ & $\mathbf{F}_{\text {tabel }}$ & Kesimpulan \\
\hline \multirow{2}{*}{ Pretes } & Eksperimen & 71.44 & \multirow{2}{*}{1.72} & 1.84 & Homogen \\
\cline { 2 - 3 } & Kontrol & 41.65 & & & \\
\hline \multirow{2}{*}{ Postes } & Eksperimen & 83.99 & \multirow{2}{*}{1.42} & 1.84 & Homogen \\
\cline { 2 - 3 } & Kontrol & 119.19 & & & \\
\hline
\end{tabular}


Tabel 4: Hasil Uji-t Data Pretes dan Posttes

\begin{tabular}{|l|c|c|c|}
\hline \multicolumn{1}{|c|}{ Data } & $\boldsymbol{t}_{\text {hitung }}$ & $\boldsymbol{t}_{\text {tabel }}$ & Kesimpulan \\
\hline Pretes & 0,77 & 2,000 & Tidak terdapat perbedaan \\
\hline Postes & 2,97 & 2,000 & Terdapat perbedaan \\
\hline
\end{tabular}

Berdasarkan perhitungan diperoleh harga $t_{\text {hitung }}=0,77$ dan $t_{\text {tabel }}=2,000$ pada taraf signifikansi $\alpha=5 \%$. Dengan kata lain, tidak terdapat perbedaan hasil kemampuan berpikir kreatif matematis siswa antara kelas eksperimen dengan kelas kontrol sebelum diberikan perlakuan.

Sedangkan untuk data post testdiperoleh hargat ${ }_{\text {hitung }}=2,97$ dan $t_{\text {tabel }}=2,000$ pada taraf signifikansi $\alpha=5 \%$. Dengan kata lain, terdapat perbedaan hasil kemampuan berpikir kreatif matematis siswa antara kelas eksperimen dengan kelas kontrol setelah diberi perlakuan.

Adapun hasil perhitungan data gain kelas eksperimen dan kelas kontrol diperoleh sebagai berikut.

Tabel 5: Rekapitulasi Data Gain

\begin{tabular}{|c|r|r|r|}
\hline \multirow{2}{*}{ Kelas } & \multicolumn{3}{|c|}{ Data Gain Ternormalisasi } \\
\cline { 2 - 4 } & Rata-Rata & Simpangan Baku & \multicolumn{1}{c|}{ Varians } \\
\hline Eksperimen & 0.76 & 0.105 & 0.011 \\
\hline Kontrol & 0.66 & 0.119 & 0.014 \\
\hline
\end{tabular}

Tabel 6: Uji Normalitas Data Gain

\begin{tabular}{|c|c|c|c|c|c|}
\hline Kelas & L maks & L table & Sig. & $\boldsymbol{\alpha}$ & Keterangan \\
\hline Eksperimen & 0.124 & 0.161 & 0.200 & 0.05 & Normal \\
\hline Kontrol & 0.160 & 0.161 & 0.042 & 0.05 & Normal \\
\hline
\end{tabular}

Berdasarkan tabel 6, dapat disimpulkan bahwa data gain kelas eksperimen dan kelas kontrol merupakan data yang menyebar normal. Sedangkan hasil perhitungan uji homogenitas data gain dengan rumus Fisher diperoleh nilai $F_{\text {hitung }}=1,27$ dengan $F_{\text {tabel }}=1,84$, sehingga dapat disimpulkan bahwa nilai gain ternormalisasi kelas eksperimen dan kelas kontrol berasal dari populasi yang homogen.

Berdasarkan perhitungan uji hipotesis data gain diperoleh $t_{\text {hitung }}=3,33$, dan $t_{\text {tabel }}=2,000$ pada taraf signifikansi $\alpha=5 \%$. Sehingga disimpulkan bahwa terdapat perbedaan peningkatan kemampuan berpikir kreatif matematis siswa yang diberi problem solving dengan siswa yang diberi strategi pembelajaran konvensional. 


\section{SIMPULAN DAN SARAN}

Berdasarkan analisis hasil dan pembahasan diperoleh hasil bahwa terdapat perbedaan kemampuan berpikir kreatif matematis siswa yang diberi pembelajaran problem solving dengansiswa yang diberi pembelajaran konvensional. Dengan nilai rata-rata gain siswa yang diberi pembelajaran problem solving lebih baik dari siswa yang diberi pembelajaran konvensional. Sehingga dapat disimpulkan bahwa penerapan strategi pembelajaran problem solving memiliki pengaruh terhadap kemampuan berpikir kreatif matematis siswa kelas VIII di SMPN 10 Tangerang tahun 2015-2016.

\section{DAFTAR PUSTAKA}

Depdiknas. (2004). STANDAR ISI, Standar Kompetensi dan Kompetensi Dasar Matematika SMA-MA. Jakarta: Dirjen Managemen Pendidikan Dasar dan Menengah, Diknas.

Depdiknas. (2006). PERMEN 22 Th.2006-STANDAR ISI, Standar Kompetensi dan Kompetensi Dasar Matematika SMA-MA. Jakarta: Dirjen Managemen Pendidikan Dasar dan Menengah, Diknas.

Djamarah, S. B. dan Zain, A. (2010). Strategi Belajar Mengajar. Jakarta: Rineka Cipta.

Driana, E. (2013). Menyikapi Hasil PISA 2012. Kompas, 6 Desember, h. 6.

Jazuli, A. (2009). Berpikir Kreatif dalam Kemampuan Komunikasi Matematika. Purwokerto: Universitas Muhammadiyah Purwokerto.

Miliyawati. (2012). Mengembangkan Keterampilan Berpikir Kreatif. Jakarta: Rajawali Pers.

Munandar, U. (2012). Pengembangan Kreativitas Anak Berbakat. Jakarta: Rineka Cipta.

National Council of Teachers of Mathematics (NCTM). (2011). Principles and Standards for School Mathematics. Reston, VA : NCTM

Sani, R. A. (2013). Inovasi Pembelajaran. Jakarta: Bumi Aksara.

Wardhani, S. (2008). Standar Isi dan Standar Kompetensi Lulusan (Implikasinya Terhadap Tugas Guru Matematika SMP/MTs dalam Pengembangan KTSP). Yogyakarta: Departemen Pendidikan Nasional.

Wena, M. (2011). Strategi Pembelajaran Inovatif Kontemporer Suatu Tinjauan Konseptual Operasional. Jakarta: Bumi Aksara.

Wibowo, Agung Edy. (2012). Aplikasi Praktis SPSS dalam Penelitian. Yogyakarta: Gava Media. 